\title{
Can percutaneous mitral balloon valvuloplasty reduce ongoing inflammation in patients with rheumatic mitral stenosis?
}

\author{
Perkütan mitral balon valvüloplasti romatizmal mitral darlı̆̆ı olan hastalardaki inflamasyonu \\ azaltabilir mi?
}

\author{
Fatih Uzun ${ }^{1}$, İsmail Bıyık², Mohammad Toib Ameri ${ }^{1}$, Mehmet Erturk ${ }^{1}$, Derya Öztürk ${ }^{1}$, Ali Kemal \\ Kalkan $^{1}$, Ahmet Arif Yalcin ${ }^{1}$, İbrahim Faruk Akturk ${ }^{3}$, Özgür Surgit ${ }^{1}$, Aydın Rodi Tosu ${ }^{1}$, Ali Birand ${ }^{1}$
}

\begin{abstract}
Objective: In the pathophysiology of rheumatic heart valve disease, chronic systemic inflammatory process plays an important role. In this study, we aimed to investigate whether the percutaneous transluminal mitral balloon valvuloplasty (PTMV) has any effect on the chronic systemic inflammatory response in patients with rheumatic mitral stenosis (RMS).
\end{abstract}

Methods: In this study, we used neutrophil to lymphocyte ratio (NLR), which is a simply available and inexpensive biomarker of systemic inflammatory response, to evaluate the level of inflammation. A total of 41 consecutive patients with severe RMS undergoing successful PTMV were included in the study. Laboratory assessments of all patients by the measuring of NLR before and after the PTMV procedure were performed.

Results: Before and after the PTMV, the mean lymphocyte counts were found $2.1 \pm 0.6 \times 10^{3} / \mu \mathrm{L}$ and $1.9 \pm 0.6$ $x 10^{3} / \mu \mathrm{L}(\mathrm{p}=0.01)$, and the mean leukocyte counts were $4.8 \pm 1.4 \times 10^{3} / \mu \mathrm{L}$ and $4.4 \pm 1.3 \times 10^{3} / \mu \mathrm{L}(\mathrm{p}=0.069)$ respectively. NLR values were determined as $2.7 \pm 1.0$ and 2.2 \pm 0.8 . After the PTMV, there was a significant decrease in NLR in patients with rheumatic mitral stenosis patients $(p=0.001)$. In the correlation analysis, there was significant negative correlation between the mitral valve area and NLR $(p=0.004-r=0.440)$, and there was significant positive correlation between left atrial diameter and NLR $(p=0.028 r=0.344)$.

Conclusion: This study showed significant decrease in NLR after PTMV in patients with RMS, which means reduced inflammation after PTMV. Larger studies are needed to confirm the results.

Key words: Rheumatic mitral stenosis, neutrophil-to-lymphocyte ratio, percutaneous mitral valvuloplasty, inflammation

\section{ÖZET}

Amaç: Romatizmal kalp kapağı hastalığı patofizyolojisinde kronik sistemik inflamatuar süreç önemli bir rol oynar. Biz bu çalışmada perkütan translüminal mitral balon valvüloplastinin (PTMV) romatizmal mitral darlığı olan hastalarda kronik sistemik inflamatuar yanıt üzerinde etkisinin olup olmadığını araştırdık.

Yöntemler: Biz bu çalışmada sistemik inflamatuar yanıtın derecesini değerlendirmek için kolay ulaşılan ve ucuz bir belirteç olan nötrofil lenfosit oranını (NLR) kullandık. Çalışmaya ciddi mitral darlığı olup başarılı PTMV yapılan toplam 41 hasta dahil edildi. Tüm hastaların NLR'si PTMV işlemi öncesinde ve sonrasında değerlendirildi.

Bulgular: PTMV öncesinde ve sonrasında ortalama lenfosit sayısı, $2,1 \pm 0,6 \times 10^{3} / \mu \mathrm{L} ; 1,9 \pm 0,6 \times 10^{3} / \mu \mathrm{L}(\mathrm{p}=0,01)$, ve ortalama lökosit sayısı 4,8 $\pm 1,4 \times 10^{3} / \mu \mathrm{L} ; 4,4 \pm 1,3 \times 10^{3} /$ $\mu \mathrm{L}(p=0.069)$ bulundu. Romatizmal mitral darlığı olan hastalarda PTMV sonrası NLR değerlerinde anlamlı düşüş saptandı. $(2,7 \pm 1,0$ ve $2,2 \pm, 8, p=0.001)$. Korelasyon analizinde mitral kapak alanı ve NLR arasında anlamlı negatif korelasyon ( $p=0,004-r=0,440)$, ve sol atrial çap ile NLR arasında anlamlı pozitif korelasyon saptandı. $(p=0,028$ $r=0,344)$.

Sonuç: Bu çalışma romatizmal mitral darlığı olan hastalarda PTMV sonrası NLR değerlerinde anlamlı düşüş göstermiştir. Bu PTMV sonrası inflamasyonun azalması anlamına gelebilir. Bu sonuçların desteklenmesi için daha büyük çalışmalara intiyaç vardır.

Anahtar kelimeler: Romatizmal mitral darlık, nötrofil lenfosit oranı, perkütan mitral valvüloplasti, inflamasyon.

\footnotetext{
${ }^{I}$ Dept. Cardiology, Mehmet Akif Ersoy Thoracic and Cardiovascular Surgery Research Hospital, Istanbul, Turkey ${ }^{2}$ Department of Cardiology, Usak State Hospital, Turkey

${ }^{3}$ Dept. Cardiology, Mehmet Akif Ersoy Thoracic and Cardiovascular Research Hospital, Istanbul, Turkey

Yazışma Adresi /Correspondence: Fatih Uzun,

Kardiyoloji Kliniği, Mehmet Akif Ersoy Gögüs Kalp ve Damar Cerrahisi EAH, Istanbul, Türkiye Email: fatihuzun28@gmail.com Geliş Tarihi / Received: 26.08.2015, Kabul Tarihi / Accepted: 30.09.2015

Copyright (C) Dicle Tıp Dergisi 2015, Her hakkı saklıdır / All rights reserved
} 


\section{INTRODUCTION}

Rheumatic mitral stenosis (RMS) being a complication of rheumatic fever (RF) has still been responsible for significant morbidity and mortality in developing countries even if this problem is steadily decreasing in developed countries [1].

Percutaneous transluminal mitral valvuloplasty (PTMV) techniques and equipments have continued to evolve over the last two decades. With this expanded experience, there has been refinement in patient selection and a clearer understanding of the benefits, limitations, and long-term results of PTMV [2]. It has become the first choice of the treatment in symptomatic severe mitral stenosis and favorable valve morphology in the absence of left atrial thrombus or moderate-to-severe MR $[2,3]$.

RMS is associated with autoimmune and inflammatory processes. The role of systemic inflammation in RMS has been documented [4,5]. As an inflammatory marker, Neutrophil to lymphocyte ratio (NLR) has been shown many diseases and It has been reported that increased NLR associated with poor prognosis in many inflammatory diseases, malignancies, cardiovascular diseases, atrial fibrillation, and heart failure in literature [6,7]. Increased NLR has recently been reported in RMS $[8,9]$.

The association between PTMV and chronic inflammation in RMS has been reported in two limited study $[10,11]$. In the present study, we aimed to investigate whether PTMV reduces the chronic systemic inflammatory response in patients with RMS.

\section{METHODS}

\section{Study population}

This study was conducted in a tertiary heart center between January 2009 and January 2014. A total of 41 consecutive patients with severe RMS undergoing successful PTMV and meeting eligibility criteria were included in the study. The exclusion criteria were acute coronary syndrome, decompensated heart failure, renal or hepatic failure, infectious diseases, autoimmune, inflammatory and connective tissue diseases, anemia (hemoglobin for women $<12$ $\mathrm{g} / \mathrm{dL}$ and for men $<13 \mathrm{~g} / \mathrm{dL}$ ) and other hematologic diseases, malignancy, chronic pulmonary diseases, substantial valvular heart disease other than mitral valvular disease, previous cardiac surgery.
The study was conducted in accordance with the Declaration of Helsinki, Good Clinical Practice (GCP) and International Conference on Harmonization (ICH) guidelines. The study protocol was approved by the ethics committee of the institution and all patients were taken written informed consent for the participation.

\section{Laboratory analysis}

We used NLR, which is a simply available and inexpensive biomarker of systemic inflammatory response, to evaluate the level of inflammation. Laboratory assessments of all patients by the measuring of NLR before and one month after the PTMV procedure were performed. The blood samples were drawn from the antecubital veins after 8 hours fasting. EDTA tubes were used for complete blood counts. Complete blood counts were analyzed with a laser based automatic analyzer (Mindray BC 5800, China).

\section{Echocardiography}

Transthoracic echocardiographic examinations were performed by experienced physicians via Vivid S5 echocardiography system with $2.5 \mathrm{mHz}$ transducer (GE-Vingmed Ultrasound AS, Horten, Norway) with standard methods according to the recommendations of the American Society of Echocardiography [12]. Ejection fraction was measured by modified Simpson's rule. Left atrial diameter (LAD) and left ventricular end-diastolic diameter (LVEDD) were measured in the parasternal long axis view with M-mode echocardiography technique. Mitral valve area was calculated with planimetric method in the parasternal short axis view at the tip of the mitral valve leaflets and the pressure half-time method with a continuous wave Doppler in apical 4-chamber view. The values were averaged. The peak and mean transmitral gradients were measured with the same method. Criteria for the diagnosis of RMS included MVA $\leq 2 \mathrm{~cm} 2$, the presence of commissural fusion, leaflet thickening, and the alteration of the subvalvular apparatus, documented by an echocardiogram [13].

\section{Statistical analysis}

Statistical analyzes were performed using the SPSS software version 17.0 for Windows (SPSS Inc., 
Chicago, Illinois, USA). Quantitative parameters are presented using means and standard deviations. Qualitative variables are expressed as numbers and percentages. In comparison of the values before and after PTMV, the Wilcoxon Signed Rank test or Paired Samples T test were used. The relations between NLR variable and left atrial diameter, systolic pulmonary artery pressure (SPAP), mitral valve area, maximal and mean pressure gradients were compared with Spearman Correlation analysis. Statistical significance level was considered to be $\mathrm{p}<0.05$.

\section{RESULTS}

A total of 41 consecutive patients with severe RMS undergoing successful PTMV, 38 of which were women, were included in the study. Baseline patient's characteristics, laboratory results, comorbidities and medications were presented in table 1 . Hematologic and echocardiographic parameters before and after PTMV were given in table 2.

Before and after the PTMV, the mean lymphocyte counts were found $2.1 \pm 0.6 \times 10 . \mathrm{e} 3 / \mu \mathrm{L}$ and $1.9 \pm 0.6 \times 10^{3} / \mu \mathrm{L}(\mathrm{p}=0.01)$, and the mean leukocyte counts were $4.8 \pm 1.4 \times 10^{3} / \mu \mathrm{L}$ and $4.4 \pm 1.3 \times 10^{3} /$ $\mu \mathrm{L}(\mathrm{p}=0.069)$ respectively. NLR values were determined as $2.7 \pm 1.0$ and $2.2 \pm 0.8$, respectively, before and after the PTMV (Figure 1).

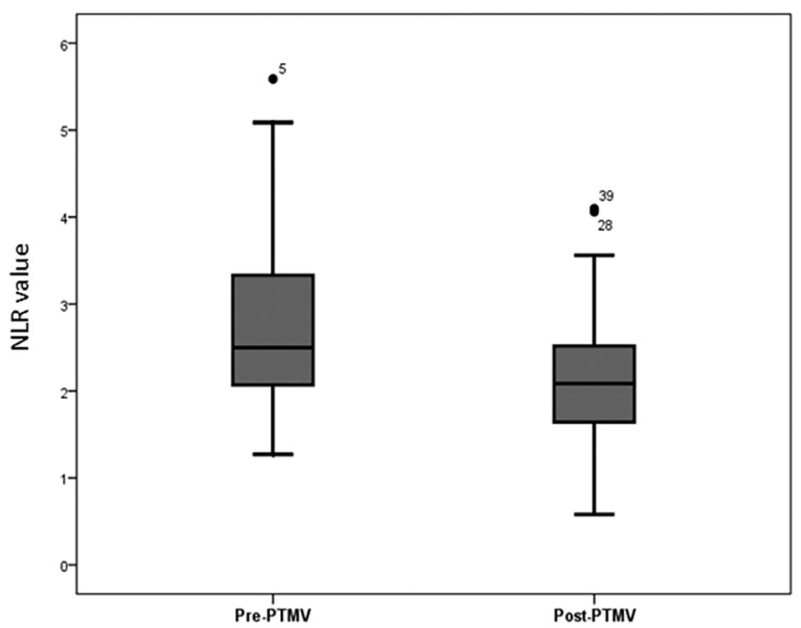

Figure 1. The graph of NLR values before and after PTMV. NLR: Neutrophil Lymphocyte Ratio, PTMV: Percutaneous Transluminal Mitral Balloon Valvuloplasty
After the PTMV, there was significant decrease in NLR in patients with RMS ( $\mathrm{p}=0.001)$ (Table 2). In the correlation analysis, there was significant positive correlation between left atrial diameter and NLR ( $\mathrm{p}=0.028 \mathrm{r}=0.344)$ and, there was significant negative correlation between the mitral valve area and NLR ( $\mathrm{p}=0.004-\mathrm{r}=0.440)$ (Table 3 and Figure 2).

Table 1. Patients characteristics, laboratory results, comorbidities and medications

\begin{tabular}{lc}
\hline Variables & $\mathrm{n}(\%)$ \\
\hline Age (years) & $42 \pm 11$ \\
Sex, female $\mathrm{n}(\%)$ & $38(92.7)$ \\
Laboratory results & \\
Hemoglobin, $(\mathrm{g} / \mathrm{dL})$ & $12.3 \pm 1.6$ \\
Platelets $\left(\mathrm{x} 10^{3} / \mathrm{\mu L}\right)$ & $237.8 \pm 70.7$ \\
Creatinine, $(\mathrm{mg} / \mathrm{dL})$ & $0.71 \pm 0.12$ \\
Comorbidities & \\
Hypertension, $\mathrm{n}(\%)$ & $6(14.6)$ \\
Coronary artery disease, $\mathrm{n}(\%)$ & $2(4.9)$ \\
Atrial fibrillation, $\mathrm{n}(\%)$ & $12(29.3)$ \\
Medications & \\
Acetyl salicylic acid & $38(92.7)$ \\
Warfarin & $12(29.3)$ \\
Diuretics & $23(56.1)$ \\
Beta blockers & $39(95.1)$ \\
Calcium channel blockers & $4(9.8)$ \\
\hline
\end{tabular}

Table 2. Hematologic and echocardiographic parameters before and after percutaneous valvuloplasty

\begin{tabular}{lccc}
\hline Variables & Pre-PTMV & Post-PTMV & p value \\
\hline WBC $(\times 10 . e 3 / \mu L)$ & $7.3 \pm 1.7$ & $7.2 \pm 1.7$ & 0.972 \\
Neutrophil $\left(\times 10^{3} / \mu L\right)$ & $4.8 \pm 1.4$ & $4.4 \pm 1.3$ & 0.069 \\
Lymphocyte $\left(\times 10^{3} / \mu L\right)$ & $1.9 \pm 0.6$ & $2.1 \pm 0.6$ & 0.011 \\
NLR & $2.7 \pm 1.0$ & $2.2 \pm 0.8$ & 0.001 \\
LVEF $(\%)$ & $62.8 \pm 4.3$ & $63.8 \pm 3.2$ & 0.033 \\
LAD $(\mathrm{mm})$ & $45.1 \pm 7.6$ & $41.7 \pm 4.4$ & $<0.001$ \\
MVA $\left(\mathrm{cm}^{2}\right)$ & $1.1 \pm 0.2$ & $1.8 \pm 0.2$ & $<0.001$ \\
Peak MSG $(\mathrm{mmHg})$ & $24.7 \pm 8.6$ & $13.3 \pm 3.4$ & $<0.001$ \\
Mean MSG $(\mathrm{mmHg})$ & $14.1 \pm 6.5$ & $5.8 \pm 2.0$ & $<0.001$ \\
SPAP $(\mathrm{mmHg})$ & $49.3 \pm 12.8$ & $35.7 \pm 6.3$ & $<0.001$ \\
\hline
\end{tabular}

NLR; Neutrophil/lymphocyte ratio, LVEF; Left ventricular ejection, LAD; Left atrial diameter, MVA; Mitral valve area, MSG; Mitral stenosis gradient, SPAP; Systolic pulmonary artery pressure 
Table 3. Correlation analysis between NLR levels and echocardiographic parameters

\begin{tabular}{lcc}
\hline Variables & \multicolumn{2}{c}{ NLR } \\
\cline { 2 - 3 } & $\mathbf{r}$ & $\mathbf{p}$ \\
\hline MVA & 0.440 & 0.004 \\
Peak MSG & 0.305 & 0.052 \\
Mean MSG & 0.281 & 0.076 \\
LAD & 0.344 & 0.028 \\
SPAP & 0.304 & 0.071 \\
\hline
\end{tabular}

MVA; Mitral valve area, MSG; Mitral stenosis gradient, LAD; Left atrial diameter, SPAP; Systolic pulmonary artery pressure

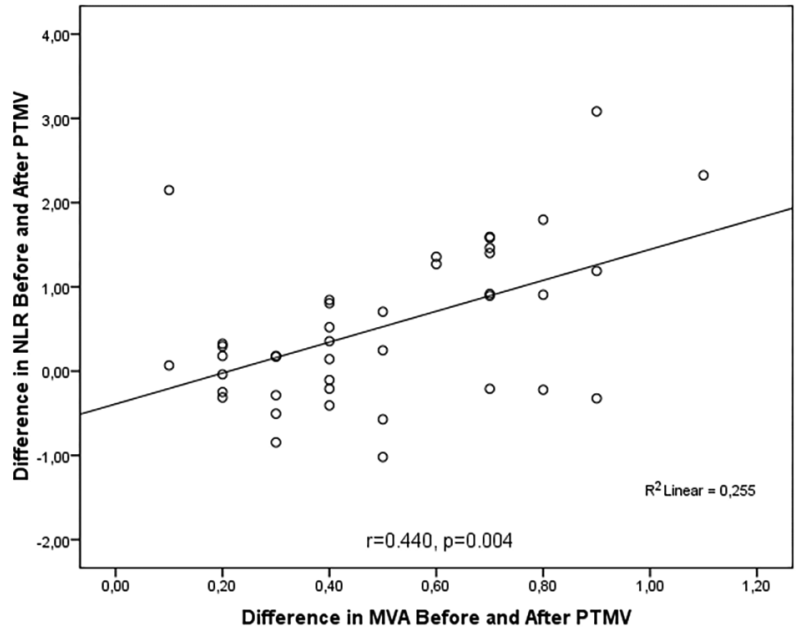

Figure 2. Correlation analysis between difference in NLR and difference in MVA before and after PTMV. . NLR: Neutrophil Lymphocyte Ratio, PTMV: Percutaneous Transluminal Mitral Balloon Valvuloplasty, MVA: Mitral Valve Area

\section{DISCUSSION}

In this study, NLR, which is a simply available and inexpensive biomarker of systemic inflammatory response, were used to evaluate the level of inflammation. After the PTMV, there was significant decrease in NLR in patients with RMS, which means reduced inflammation after PTMV. There were significant correlations between NLR and the mitral valve area and left atrial diameter, also.

In acute RF, there are inflammation and edema of the leaflets; it has been believed that the repeated episodes of the carditis associated with RF are responsible for chronic rheumatic valve disease, characterized by the deposition of fibrous tissue $[4,14]$. On the other hand, the role of continuous inflammation has strongly been put forward by different studies of inflammation markers [4,8-11,14-23].
Polat and Akboga et al have found that high NLR is associated with RMS and the severity of the stenosis $[8,9]$. Rifae and Chen et al reported that high interleukin 6 levels and high CD 40 levels are associated with RMS [10,11]. Golbasi, Atalar and Krasuski et al showed that high sensitive C-reactive protein levels are higher in patients with RMS and there is a role of ongoing chronic inflammation in RMS $[4,14,15]$. Akboga et al have recently pointed out that there is an association between red blood cell distribution width and the presence and the severity of RMS [16]. Chiu-Braga et al observed that significantly elevated levels of advanced oxidation protein products and high sensitive C-reactive protein were in patients with rheumatic valvular disease (RVD) [17]. Banerjee et al showed high levels of collagen metabolism markers in patients with RVD [18]. Pulimamidi et al presented that increased levels of markers of oxidative stress and inflammation in patients with RMS predispose to left atrial thrombus formation [19]. Caglı et al reported that plasma levels of tumor necrosis factor-alpha and soluble TNF receptor increase in RMS [20]. Mukherjee et al pointed out the role of the complement and coagulation cascade in RMS patients [21]. Recently, Ozturk et al reported that high NLR and ongoing inflammation is associated with the development of left atrial spontaneous echocardiographic contrast and thrombus formation [22]. Further evidence of ongoing inflammation in RMS is supported by other studies [23].

However, there is no clear evidence about whether increased inflammation increases the severity of stenosis or increased stenosis raises the severity of inflammation. Ostovan et al reported that there is no association between high sensitive C-reactive protein levels and mitral valve restenosis after PTMV [24]. On the other hand, Rifaie et al suggested that chronic ongoing inflammation may have a role in the development of restenosis after PTMV in RMS [10]. Chen et al pointed out that PTMV reduces the inflammation in RMS patients [11]. Our result is consistent with this study and supports reduced inflammation after PTMV in RMS patients.

This study does have some limitations. Major limitations of the present study are small number of patients, single centered design, and that there is no information about the association between reste- 
nosis and inflammation after PTMV. Despite these limitations, it is of importance in terms of showing that NLR may be useful marker to show reduced inflammation after PTMV and to follow up the inflamatuar state after PTMV in RMS.

In conclusion, this study showed significant decrease in NLR after PTMV in patients with RMS, which means reduced inflammation after PTMV. Further studies are needed to confirm the results.

\section{Acknowledgement}

\section{Funding source: None}

Declaration of interest: The authors report no conflict of interest. The authors alone are responsible for the content and writing of the paper.

\section{REFERENCES}

1. Otto CM, Bonow RO. Valvular heart disease. In Libby P, Bonow RO, Mann DL, Zipes DP. Braunwald's heart disease, A textbook of cardiovascular medicine. 8th edn. Philadelphia, USA, Saunders Elsevier, 2008:1646-1647.

2. Yıldız A, Kaya H, Ertaş F, et al. Short-term follow-up results of percutaneous mitral balloon valvuloplasty: A single-center experience. Dicle Med J 2014;41:695-699.

3. Nishimura RA, Otto CM, Bonow RO, et al. American College of Cardiology/American Heart Association Task Force on Practice Guidelines. 2014 AHA/ACC guideline for the management of patients with valvular heart disease: a report of the American College of Cardiology/American Heart Association Task Force on Practice Guidelines. J Am Coll Cardiol 2014;63:e57-185.

4. Golbasi Z, Ucar O, Keles T, et al. Increased levels of high sensitive C-reactive protein in patients with chronic rheumatic valve disease: evidence of ongoing inflammation. Eur J Heart Fail 2002;4:593-595.

5. Yetkin E, Erbay AR, Ileri M, et al. Levels of circulating adhesion molecules in rheumatic mitral stenosis. Am J Cardiol 2001;88:1209-1211.

6. Templeton AJ, McNamara MG, Šeruga B, et al. Prognostic role of neutrophil-to-lymphocyte ratio in solid tumors: a systematic review and meta-analysis. J Natl Cancer Inst 2014; 106: dju124.

7. Bhat T, Teli S, Rijal J, et al. Neutrophil to lymphocyte ratio and cardiovascular diseases: a review. Expert Rev Cardiovasc Ther 2013;11:55-59.

8. Polat N, Yildiz A, Yuksel M, et al. Association of Neutrophil-Lymphocyte Ratio With the Presence and Severity of Rheumatic Mitral Valve Stenosis, Clinical and Applied Thrombosis/Hemostasis 2014;20:793-798.

9. Akboğa MK, Akyel A, Şahinarslan A, et al. Neutrophil-tolymphocyte ratio is increased in patients with rheumatic mitral valve stenosis? Anatol J Cardiol 2015;15:380-384.

10. Rifaie O, Omar AM, Abdel-Rahman MA, et al. Does a chronic inflammatory state have a role in the development of mitral restenosis after balloon mitral valvuloplasty? Int J Cardiol 2014;172: e417-418.

11. Chen MC, Chang HW, Wu CJ, et al. Percutaneous transluminal mitral valvuloplasty reduces circulating soluble CD40 ligand in rheumatic mitral stenosis. Chest 2005;128:36-41.

12. Quinones MA, Otto CM, Stoddard M, et al. Recommendations for quantification of Doppler echocardiography: a report from the Doppler quantification task force of the nomenclature and standards committee of the American society of echocardiography. J Am Soc Echocardiogr 2002;15:167-184.

13. Horstkotte D, Niehues R, Strauer BE. Pathomorphological aspects, aetiology and natural history of acquired mitral valve stenosis. Eur Heart J 1991;12; suppl B:55-60.

14. Atalar E, Ozturk E, Ozer N, et al. Plasma soluble osteopontin concentrations are increased in patients with rheumatic mitral stenosis and associated with the severity of mitral valve calcium. Am J Cardiol 2006;98:817-820.

15. Krasuski RA, Bush A, et al. C-reactive protein elevation independently influences the procedural success of percutaneous balloon mitral valve commissurotomy. Am Heart J 2003;146:1099-1104.

16. Akboğa MK, Abacı A, Canpolat U, et al. Association of red blood cell distribution width with presence and severity of rheumatic mitral valve stenosis. Turk Kardiyol Dern Ars 2015;43:227-233.

17. Chiu-Braga YY, Hayashi SY, Schafranski M, et al. Further evidence of inflammation in chronic rheumatic valve disease (CRVD): high levels of advanced oxidation protein products (AOPP) and high sensitive C-reactive protein (hsCRP). Int J Cardiol 2006;109:275-276.

18. Banerjee T, Mukherjee S, Ghosh S, et al. Clinical significance of markers of collagen metabolism in rheumatic mitral valve disease. PLoS One 2014;9:e90527.

19. Pulimamidi VK, Murugesan V, Rajappa M, et al. Increased levels of markers of oxidative stress and inflammation in patients with rheumatic mitral stenosis predispose to left atrial thrombus formation. J Clin Diagn Res 2013;7:24452448.

20. Cagli KE, Aras D, Topaloglu S, et al. S. Plasma levels of tumor necrosis factor-alpha and its receptors in patients with mitral stenosis and sinus rhythm undergoing percutaneous balloon valvuloplasty. Heart Vessels 2010;25:131-137.

21. Mukherjee S, Jagadeeshaprasad MG, Banerjee T, et al. Proteomic analysis of human plasma in chronic rheumatic mitral stenosis reveals proteins involved in the complement and coagulation cascade. Clin Proteomics 2014;11:35.

22. Ozturk D, Erturk M, Celik O, et al. The role of the neutrophil/lymphocyte ratio in patients with rheumatic mitral stenosis as an indicator of spontaneous echocardiographic contrast. Kardiol Pol 2014;72:969-976.

23. Chopra P, Gulwani H. Pathology and pathogenesis of rheumatic heart disease. Indian J Pathol Microbiol 2007;50:685697.

24. Ostovan M, Aslani A, Abounajmi S, et al. Mitral valve restenosis after percutaneous transmitral valvuloplasty, role of continuous inflammation. J Cardiovasc Thorac Res 2014;6:191-195 